\title{
DRUG CONTROL IN MASSACHUSETTS
}

The increasingly pervasive problem of drug abuse in contemporary American society necessitates a firm response from the state. But the seriousness of the abuse problem does not justify overly repressive measures unduly inhibiting individuals in the free exercise of their constitutional rights. Recognizing the power of the state to deal effectively with the broad range of difficulties posed by the use of narcotic drugs, ${ }^{1}$ this Comment examines the constitutional implications of one Massachusetts statute designed to control that state's narcotics problems. ${ }^{2}$

The greater part of Massachusetts' drug law is modeled after the Uniform Narcotics Drug Act, ${ }^{3}$ the basic statutory scheme in a number of states. In 1960, however, the Massachusetts legislature enacted an additional provision of its own drafting, section $213 \mathrm{~A}$, reading in part:

Whoever is present where a narcotic drug is illegally kept or deposited, or whoever is in the company of a person, knowing that said person is illegally in possession of a narcotic drug . . . may be arrested . . . and may be punished by imprisonment in the state prison for not more than five years .... ${ }^{4}$

The section contains two distinct clauses: the "presence clause" punishes one present where drugs are illegally kept; the "companionship clause," one in the company of anyone in illegal possession of narcotics.

The effect of a literal interpretation of the "presence clause" is devastating. Because the clause does not require knowledge, potential culpability could reach absurd extremes. Were a spectator in Boston's New Court House illegally possessed of narcotics, the entire courtspectators, jurors, attorneys, and judges-would be guilty of a felony under the language of the statute. ${ }^{5}$ Although the Commonwealth has utilized the statute to arrest persons unknowingly present where a nar-

1 The Supreme Court has indicated that the states have broad police powers in this area. See Robinson v. California, 370 U.S. 660, 664-65 (1962).

2 Although this Comment is concerned primarily with a single state statute, the problems discussed are not limited to Massachusetts. For example, in 1969 the New Hampshire legislature enacted a similar provision. N.H. Rev. Stat. AnN. \$318B :26(II) (Supp. 1969). (1968).

${ }^{3}$ Commonwealth v. Buckley, 354 Mass. 508, 510 n.2, 238 N.E.2d 335, 336-37 n.2

4 Mass. Ann. Laws ch. 94, §213A (1967).

5 See Brief for Defendant at 9, Commonwealth v. Buckley, 354 Mass. 508, 238 N.E.2d 335 (1968) [hereinafter cited as Buckley Brief]. 
cotic drug was illegally kept, ${ }^{6}$ the Supreme Judicial Court of Massachusetts rejected the state's characterization of the statute as a "public welfare" statute ${ }^{7}$ and held in Commonwealth $v$. Buckley ${ }^{8}$ that knowledge was required to sustain a conviction under the "presence clause." This scienter limitation, however, does not significantly restrict the reach of the clause, for one aware of the presence of illegal narcotics must now withdraw from the area or risk five years' imprisonment regardless of whether he is attending a private party, a public folk concert, a night club, or is merely present in a dormitory suite.

Because the "companionship clause" expressly requires knowledge and because most of its terms have well-established meanings, only the phrase "in the company of" was susceptible to judicial definition. In Commonwealth $v$. Tirella, ${ }^{9}$ the court interpreted this phrase to require "something that smacks of fellowship" 10 to bring an individual within the clause's proscription; mere presence in the same place was insufficient to violate the statute.

This Comment will discuss the constitutional implications of section 213A as interpreted in Buckley and Tirella. It will explore (1) whether the statute is unconstitutionally vague, (2) whether it constitutes cruel and unusual punishment, (3) whether it allows an impermissible inference of guilt based on mere association, and (4) whether it abridges freedom of association. A brief review of both cases will set the stage for the constitutional discussion.

\section{Buckley and Tirella: Facts and Opintons}

William G. Buckley was arrested in the apartment of an acquaintance in Boston and charged with being present where a narcotic was illegally kept. The police entered the premises only a few minutes after Buckley's arrival and found him seated at a kitchen table on which they discovered an extinguished cigarette butt and an envelope, both containing marijuana. ${ }^{11}$ Holding the statute not unconstitutionally vague, the court found that the "presence clause" required knowledge by the accused of the facts necessary to establish his culpability. The opinion summarily rejected Buckley's contentions that the statute abridged his freedom of association or his right to be free from cruel and unusual punishment.

6 For example, on 26 April 1968, police raided a Boston nightclub, arrested all 76 patrons, and charged them with violations of $\$ 213 \mathrm{~A}$. Fifty of those arrested consulted with the Civil Liberties Union, protesting that they were unaware that marijuana was present in the nightclub. Id.

7 See Brief for Commonwealth at 5-7, Commonwealth v. Buckley, 354 Mass. 508, 238 N.E.2d 335 (1968) [hereinafter cited as Commonwealth Brief].

8354 Mass. 508, 238 N.E.2d 335 (1968).

9 355 Mass. -, 249 N.E.2d 573 (1969).

$10 \mathrm{Id}$. at -, 249 N.E.2d at 575.

11 Commonwealth Brief 2. 
John A. Tirella was arrested and convicted under the "companionship clause" after an officer of the police narcotics unit observed the driver of an automobile in which he was a passenger purchase heroin from a pedestrian. The court rejected each of Tirella's several constitutional attacks upon the second clause of section 213A. Narrowly interpreting the phrase "in the company of," the court held the statute not void for vagueness because the phrase was definite enough to permit men of common intelligence to understand its meaning. ${ }^{12}$ Relying without elaboration on the Buckley holding, the majority found that section 213A neither abridges freedom of association nor imposes cruel and unusual punishment. ${ }^{13}$ The court avoided Tirella's contention that the statute permitted an inference of guilt of the crime of possession from proof of mere association and held that the legislature had created a new substantive offense-the act of association itself. ${ }^{14}$ Thus the court found it unnecessary to inquire into the rationality of any legislative presumption of criminal behavior based upon the defendant's association with a possessor. This facile resolution of important constitutional questions and the strong opposition of the dissenting opinion ${ }^{15}$ raise the need for a deeper analysis of the issues decided in Buckley and Tirella.

\section{VOID FOR VAGUENESS}

\section{A. The "Presence Clause"}

Relying on the standard test that "a law forbidding or requiring conduct in terms so vague that men of common intelligence must necessarily guess at its meaning and differ as to its application violates due process of law,"16 Buckley argued that the phrase "present where" in section $213 \mathrm{~A}$ established a standard of conduct he could not be expected to determine on his own. But the Massachusetts court disagreed:

These words [whoever is present], coupled with knowledge, do not import an unlimited area. The words must be given a reasonable interpretation which would permit the knowledge required to be proved. The language reasonably refers to a somewhat restricted space. ${ }^{17}$

In Comally v. General Construction Co., ${ }^{18}$ the United States Supreme Court used the test relied upon by Buckley to hold invalid an

12 See text accompanying note 21 infra.

13355 Mass. at -, 249 N.E.2d at 576.

14 See id. at 一, 249 N.E.2d at 576.

15 Id. (Spalding, Whittemore, \& Reardon, JJ., dissenting).

16 Buckley Brief 3 (citing Baggett v. Bullitt, 377 U.S. 360,367 (1964)).

17354 Mass. at 513, 238 N.E.2d at 338.

18269 U.S. 385 (1926). 
Oklahoma minimum wage law making criminal a failure to pay the "current rate of per diem wages in the locality where the work is performed" to persons employed by or on behalf of the state. ${ }^{19}$ Finding the word "locality" inherently vague, the Court noted that:

Two men moving in any direction from the place of operations, would not be at all likely to agree upon the point where they had passed the boundary which separated the locality of that work from the next locality. ${ }^{20}$

The term "present where" in section $213 \mathrm{~A}$ is similarly ambiguous: must a person finding himself "present where a narcotic drug is illegally kept or deposited" leave a nightclub, sporting event, or concert, or may he avoid violating the statute merely by moving from the immediate vicinity of the contraband? The nature of the conduct proscribed necessitates an explicit definition. A violation of a statute prohibiting the possession or sale of narcotics is clearly intentional, but a section $213 \mathrm{~A}$ violation may result when an individual unexpectedly finds himself in the presence of narcotics. The state should define with utmost clarity how far and how fast he must flee to escape the reach of the statute.

\section{B. The "Companionship Clause"}

The Tirella court sought to counter the defendant's argument that the "companionship clause" was vague by narrowly defining the term "in the company of," but its attempted definition merely increased the vagueness of the clause.

The meaning of the phrase "in the company of a person" in the second clause of $\S 213 \mathrm{~A}$ requires a . . . strict interpretation. We think that for conviction under it there must be proof of more than that the defendant merely was found in the same place with a person known by the defendant to possess narcotics. . . . [T] he words "in the company of" imply "something that smacks of fellowship . . . [or] companionship, friendly intercourse, and the like." Coupled with the requirement (in the second clause) of knowledge of the illegal possession of a narcotic by the companion, the words import (a) acquiescent association with another, known to possess narcotics, and (b) an absence of prompt and adequate objection by the defendant to the illegal possession. A violation of the second clause of $\S 213 \mathrm{~A}$ is made out by proof that the defendant had more than casual or momentary association with another, with knowledge of the latter's illegal possession, unless the defendant shows facts constituting justification or 
excuse (as, for example, inability to withdraw after acquiring knowledge of possession, or reasonable cause for remaining such as that he was a relative, priest, or doctor attempting to discourage continued violation or, possibly, that other exculpatory circumstances existed). ${ }^{21}$

This purported clarification is confusing and contradictory. In one sentence the court suggests that "prompt and adequate objection" to the illegal activities might excuse an apparent violation, but in the next clearly implies that the defendant has an affirmative duty to depart in all but extraordinary circumstances. The court's offhanded suggestion of other possible exculpatory circumstances offers little solace to an individual unable to determine the basic elements of the offense with which he is charged. ${ }^{22}$

\section{iII. Cruel and Unusual Punishment}

Citing only Robinson v. California, ${ }^{23}$ Tirella argued that the possible imposition of five years' imprisonment for violations of section $213 \mathrm{~A}$ constituted cruel and unusual punishment prohibited by the eighth and fourteenth amendments. ${ }^{24}$ But Robinson offers scant support for this claim. The Supreme Court held unconstitutional a California statute permitting incarceration for narcotics addiction, deciding that a state could not imprison an individual afflicted with an illnessaddiction.

Commentary on Robinson has suggested at least three possible rationales for the Court's decision. ${ }^{25}$ Under the first, statutes punishing "pure status" would constitute cruel and unusual punishment. ${ }^{26}$ Embracing laws defining crimes in terms of personal characteristics rather than acts, this rationale would not apply to section $213 \mathrm{~A}$, which condemns the specific acts of being present or associating. A second interpretation of Robinson would invalidate statutes penalizing a person for a condition from which he is unable to extricate himself, or for acts associated with such a condition. ${ }^{2 \pi}$ This interpretation would

21355 Mass. at - 249 N.E.2d at 575.

22 The relatively recent enactment of $\$ 213 \mathrm{~A}$ 's companionship clause, see 355 Mass. at,- 249 N.E.2d at $574 \mathrm{n} .1,575 \mathrm{n} .2$, presents another possible ground for a vagueness attack: the legislature failed to act with sufficient precision in defining the contours of newly prohibited activity. See Lanzetta v. New Jersey, 306 U.S. 451, 453 (1939); Connally v. General Constr. Co., 269 U.S. 385, 391 (1926); Note, The Void-forVagueness Doctrine in the Supreme Court, 109 U. PA. L. Rev. 67, 84 (1960) ("[L] egislation creating 'new' crimes . . . is particularly vulnerable to vagueness attack.").

23370 U.S. 660 (1962).

24 Brief for Defendant at 7, Commonwealth v. Tirella, 355 Mass. -, 249 N.E.2d 573 (1969) [hereinafter cited as Tirella Brief].

25 Note, The Cruel and Unusual Punishment Clause and the Substantive Criminal Laze, 79 HARv. L. REv. 635, 646-50 (1966).

26 Id. 650 .

27 Id. $650-54$. 
invalidate a conviction under section $213 \mathrm{~A}$ only if the defendant was unable to remove himself from the vicinity of the illicitly held drugs or from the company of a possessor. A third rationale merely qualifies the other two interpretations of Robinson by considering the voluntariness of an individual's acquisition of his condition. A statute could constitutionally punish only voluntarily acquired conditions or voluntary acts. ${ }^{28}$ Because section $213 \mathrm{~A}$ prohibits only voluntary acts, punishment would not be invalid under this theory of Robinson.

Section 213A may also be sustained under the more traditional interpretation of the eighth amendment as prohibiting only inherently cruel punishments. ${ }^{29}$ In Trop v. Dulles, ${ }^{30}$ Chief Justice Warren noted that " $[\mathrm{t}]$ he basic concept underlying the Eighth Amendment is nothing less than the dignity of man." 31 Only punishments denying the humanity of the criminal are unconstitutional. ${ }^{32}$ But neither clause of section $213 \mathrm{~A}$ imposes an inhuman penalty.

A final possible interpretation of the eighth amendment, however, supports a challenge to the Massachusetts statute. In Weems $v$. United States, ${ }^{33}$ the Supreme Court reversed a conviction for falsification of documents under a Philippine statute establishing a minimum penalty of twelve-years and one-day confinement in chains at hard labor plus the loss of numerous civil rights. Comparing this penalty with those for crimes generally considered more serious, the Court concluded that the sentence required by the statute was cruelly excessive, for even the crime of forgery or of counterfeiting United States securities permitted only a fifteen-year maximum and a fine, but no similar loss of civil rights.

Under the provisions of the Massachusetts narcotics laws, various crimes generally considered more serious than a $213 \mathrm{~A}$ violation may be punished with the same sentence as authorized by the latter section. For example, possession of heroin, ${ }^{34}$ sale of narcotics, ${ }^{35}$ possession of narcotics for sale, ${ }^{36}$ or stealing of narcotics ${ }^{37}$ may result in merely a five-year prison term for a first offender-the same penalty which may be imposed as a maximum for a violation of section 213A. A com-

28 Id. 654-55.

29 See In re Kemmler, 136 U.S. 436, 447 (1890); Note, Revival of the Eighth Amendment: Development of Cruel-Punishment Doctrine by the Supreme Court, 16 StaN. L. REV. 996, 997 (1964). In upholding death by electrocution, the Court stated in Kemmler: "[Cruel and unusual punishment] implies . . something inhuman and barbarous, something more than the mere extinguishment of life." 136 U.S. at 447.

30356 U.S. 86 (1958). The Court held unconstitutional a statute stripping a wartime deserter of his citizenship. Three Justices concurred in Chief Justice Warren's view that this was cruel and unusual punishment.

31 Id. at 100 .

32 Note, supra note 29 , at 1002 .

33217 U.S. 349 (1910).

34 Mass. Ans. Laws ch. 94, \$212 (1967).

35 Id. $\$ 217$.

36 Id. \$217B.

$37 \mathrm{Id} . \S 217 \mathrm{C}$. 
parison of the maximum penalties for possession of narcotics (three and one-half years) ${ }^{38}$ and for being in the company of one illegally in possession of narcotics (five years) ${ }^{39}$ exposes an anomaly in the statutory scheme: the companion of the illegal possessor could receive a harsher sentence than the possessor himself. An application of the Weems rationale to this situation might result in a declaration that section $213 \mathrm{~A}$ authorizes a cruelly excessive sentence. ${ }^{40}$

\section{Inference of Guilt from Proof of Association}

Criminal statutes penalizing mere presence or association are rare. The common law has generally viewed presence at the scene of a crime as an act without culpability and has attached criminal penalties only to presence or association evidencing an active encouragement of illegal activity. ${ }^{41}$ But a statute prohibiting certain types of association may be an attempt to eliminate an underlying evil not easily attacked directly. Tirella argued that section $213 \mathrm{~A}$ was such a statute, because it established a presumption of guilt of illegal narcotics activity from proof of companionship or presence. ${ }^{42}$ Under this interpretation, the constitutionality of the statute could have been sustained only by demonstrating the presumption's rationality. ${ }^{43}$

In Tot v. United States, ${ }^{44}$ the Supreme Court articulated a test for evaluating a statutory presumption similar to that found in section 213A. Upon a showing of possession, the Federal Firearms Act ${ }^{45}$ permitted conviction for unlawful receipt ${ }^{46}$ of a firearm or ammunition transported in interstate or foreign commerce. Possession of the firearm established a presumption that it had moved in commerce. In holding this presumption violative of due process, the Court stated:

[A] statutory presumption cannot be sustained if there be no rational connection between the fact proved and the ultimate fact presumed, if the inference of the one from proof of the other is arbitrary because of lack of connection between the two in common experience. ... [W] [Were the inference is

$38 I d . \S 205$. This section does not penalize possession of heroin, an independent offense punished under $i d . \$ 212$.

39 Id. $\$ 213 \mathrm{~A}$.

40 The Massachusetts court rejected a similar challenge to the narcotics laws as applied to marijuana, on the grounds that the statute provides for no mandatory minimum sentence and that the sentencing judge can be trusted to use his discretion wisely. Commonwealth v. Leis, 355 Mass. -, 243 N.E.2d 898, 906 (1969). But this sentencing discretion merely increases the danger articulated by the dissenting justices in Tirella that $\$ 213 \mathrm{~A}$ may be used discriminatorily as a dragnet statute. 355 Mass. at,- 249 N.E.2d at 577.

11 R. Anderson, Wharton's Criminal Law and Procedure 108 (1957).

12 Tirella Brief 5-6.

43 See, e.g., Tot v. United States, 319 U.S. 463, 467-68 (1943).

44319 U.S. 463 (1943).

45 Ch. 850, §2(f), 52 Stat. 1251 (1938).

46 Receipt was unlawful for individuals who had been convicted of a crime of violence, or were fugitives from justice. Id. 
so strained as not to have a reasonable relation to the circumstances of life as we know them, it is not competent for the legislature to create it as a rule governing the procedure of courts. ${ }^{47}$

The Court has followed this test in subsequent decisions. ${ }^{48}$ In United States $v$. Gainey, ${ }^{49}$ the majority sustained the inference that unexplained presence at an illegal still evidenced participation in illicit distillation, because it felt that anyone so present must play some part in the enterprise. In United States $v$. Romano, ${ }^{50}$ however, the Court invalidated a similar presumption that presence at a still was sufficient evidence to permit conviction on a charge of possession, custody, and control of the still. The Court noted:

Presence is relevant and admissible evidence in a trial on a possession charge; but absent some showing of the defendant's function at the still, its connection with possession is too tenuous to permit a reasonable inference of guilt . . . ${ }^{51}$

More recently, in Leary $v$. United States, ${ }^{52}$ the Court held invalid the statutory inference that a possessor of marijuana knew of its illegal importation. Because a substantial amount of marijuana is grown domestically, a possessor would not likely know that his marijuana was illegally imported.

If intended to deter other, more serious narcotics violations by the defendant, section $213 \mathrm{~A}$ rests upon the presumption that those discovered in the presence of narcotics or in the company of a possessor are also engaged or likely to engage in unlawful activity. But this presumption is of questionable validity at best. Individuals associate with one another for many reasons, and the activity covered by section $213 \mathrm{~A}$ in no way necessarily correlates with the commission of more serious narcotics violations by those associating with possessors.

The Tirella court never had to resolve this issue, however, for it rejected the view that section 213A established a legislative presumption of guilt of serious narcotics violations from proof of presence or association and held that the Massachusetts legislature had prohibited the act of association itself. ${ }^{53}$ The statute imposed a coercive ostracism upon those knowingly violating the Commonwealth's other narcotics laws. Although neatly avoiding the issue of the rationality of any

47319 U.S. at $467-68$ (footnote omitted).

48 See, e.g., Turner v. United States, 396 U.S. 398, 404-05 (1970); Leary v. United States, 395 U.S. 6, 32-34 (1969); United States v. Romano, 382 U.S. 136, 139 (1965) ; United States v. Gainey, 380 U.S. 63, 66-68 (1965).

49380 U.S. 63 (1965).

50382 U.S. 136 (1965).

51 Id. at 141.

52395 U.S. 6 (1969).

53355 Mass. at -, 249 N.E.2d at 576. 
legislative presumption, this interpretation of the statute exposed a more fundamental difficulty-the legislature's power to curtail free association.

\section{Due Process and the Right to Associate}

The Tirella court dealt summarily with the constitutional problems posed by an interpretation of section $213 \mathrm{~A}$ as proscribing association with an illegal possessor of narcotics to deprive him "of any encouragement which may be given by acquiescent companionship." 54 It relied exclusively upon the unreasoned holding in Buckley that the "presence clause" of section $213 \mathrm{~A}$ did not abridge any right of association to rebut a similar attack against the "companionship clause." But this approach ignored the difference between the two clauses: the "presence clause" abridges association between individuals only incidentally, but the "companionship clause" is directed primarily toward associative conduct. .5

Although appealing on its face, a claim that a right of free association has been abridged raises several difficulties when applied to the Massachusetts statute. First, the doctrine of free association has not been fully developed, in part because of its comparatively recent formulation. ${ }^{56}$ Second, commentators have generally discussed the doctrine in the context of the first amendment and political association. ${ }^{57}$ But the due process clauses of the fifth and fourteenth amendments afford protection to the association affected by section $213 \mathrm{~A}$.

In Scales v. United States, ${ }^{58}$ the Supreme Court squarely faced the question whether mere membership in a group, or association with persons who advocate the violent overthrow of the government, justifies the imposition of criminal sanctions. Although the opinion dealt in part with first amendment freedoms, the Court sustained the federal statute $^{5 \theta}$ against a fifth amendment due process attack, carefully defining the constitutionally permissible scope of criminal liability for mere association. Writing for the majority, Mr. Justice Harlan set strict standards for determining culpability:

$54 I d$.

55 Although most relevant to the "companionship clause," the following discussion also applies to the "presence clause" insofar as an individual could be prosecuted for being in the presence of an illegal possessor. For example, Tirella might have been convicted under the "presence clause" for being in a car in which he knew narcotics were illegally kept. Under these circumstances, the impact of the presence clause upon association should be judged by the same constitutional standards applied to the companionship clause.

56 See Emerson, Freedom of Association and Freedont of Expression, $74 Y_{\mathrm{ALE}}$ I.J. 1 (1964). Emerson views the right of association as originating with the 1958 Supreme Court decision in NAACP v. Alabama ex rel. Patterson, 357 U.S. 449 (1958).

57 For a typical discussion, see Emerson, sutpra note 56.

58367 U.S. 203 (1961).

50 Act of June 25, 1948 (Smith Act), ch. 645, \$2385, 62 Stat. 808, as annended 18 U.S.C. $\$ 2385$ (1964) (prohibiting membership in organizations advocating the violent overthrow of the government). 
In our jurisprudence guilt is personal, and when the imposition of punishment on a status or on conduct can only be justified by reference to the relationship of that status or conduct to other concededly criminal activity . . . that relationship must be sufficiently substantial to satisfy the concept of personal guilt in order to withstand attack under the Due Process Clause.... ${ }^{60}$

The kind of association protected in Scales is strikingly similar to that found criminal under section $213 \mathrm{~A}$. Like that section, the federal statute challenged in Scales apparently imposed sanctions on inactive members or associates. Although interpreting the statute to require some "active" membership_conduct furthering the unlawful purpose of the group-the Court clearly implied that passive association with wrongdoers could not be constitutionally prohibited:

It must indeed be recognized that a person who merely becomes a member of an illegal organization, by that "act" alone need be doing nothing more than signifying his assent to its purposes and activities on one hand, and providing, on the other, only the sort of moral encouragement which comes from the knowledge that others believe in what the organization is doing. It may indeed be argued that such assent and encouragement do fall short of the concrete, practical impetus given to a criminal enterprise which is lent for instance by a commitment on the part of a conspirator to act in furtherance of that enterprise. ${ }^{61}$

Although not explicitly based on a right of association, ${ }^{62}$ this reasoning supports the proposition that companionship or presence alone is not constitutionally punishable. A specific criminal act may be unnecessary to attach guilt, but some support directly furthering conduct the state may legitimately prohibit is essential. The punishment of companions to reduce the incidence of a forbidden activity is unconstitutional. ${ }^{63}$

The protection afforded association by Scales suggests that the constitutionality of section 213A should be judged in light of the availability of less restrictive means for accomplishing the legislative

60367 U.S. at 224-25.

$61 I d$. at $227-28$.

62 In its discussion of first amendment issues, the Scales Court explicitly recognized a right of association. Id. at 229.

63 In the absence of a statute, the Massachusetts court has refused to permit conviction of a substantive crime upon evidence of mere association. In Commonwealth v. Fancy, 349 Mass. 196, 207 N.E.2d 276 (1965), the court reversed Fancy's conviction for the theft of liquor. The defendant's association with the convicted thief, however suspicious, was insufficient to establish his guilt. The Massachusetts court has thus acted in accord with judicial opinion repudiating guilt by association as a basis for imposing criminal sanctions. See Uphaus v. Wyman, 360 U.S. 72, 79 (1959); cf. United States v. Robel, 389 U.S. 258, 265 (1967). 
purpose. ${ }^{64}$ Assuming that the purpose of the Massachusetts legislature is to curtail the possession and dissemination of dangerous drugs, clearly less restrictive means are available to accomplish this result. ${ }^{65}$ Stiffer penalties for use or possession, more vigorous enforcement of other, narrower regulatory measures, or chemical tests to identify narcotics users all deter drug abuse, but have no effect on companions or guests of an illegal possessor. Although section 213A may possibly be an effective tool for controlling drug abuse, both the rationality and the constitutionality of prohibiting companionship or presence to solve the abuse problem are doubtful in light of the availability of less restrictive alternatives.

Other, less explicit constitutional doctrines also cast doubt on the validity of the Massachusetts statute. When important personal rights were involved, the Supreme Court has occasionally overturned statutes without closely tying its decision to a specific provision of the Constitution. Whether such decisions result from considerations of the fundamentals of an American scheme of ordered liberty, ${ }^{86}$ from circumstances shocking to the Court's conscience, ${ }^{67}$ or from an analysis of penumbras emanating from the Bill of Rights, ${ }^{68}$ they express "longrange community values perceived by the judiciary but not necessarily reflected by the Constitution." 69

Conduct analogous to that proscribed by section $213 \mathrm{~A}$ has been protected under constitutional doctrines such as those enumerated above. For example, Griswold v. Connecticut ${ }^{\mathrm{T}}$ and Loving v. Virginia $^{71}$ both indicate that association in marriage merits special protection from state regulation. The state may not unduly restrict at least certain kinds of association. Although dicta in Tirella implies that section $213 \mathrm{~A}$ does not prohibit contact with relatives, doctors, or spiritual advisors, ${ }^{72}$ the state's power to deprive a narcotics violator of other types of companionship is questionable.

\section{CONCLUSION}

This Comment has examined various constitutional challenges to a Massachusetts statute attempting to reduce drug abuse. In upholding the statute in Buckley and Tirella, the Supreme Judicial Court of

64 See Aptheker v. Secretary of State, 378 U.S. 500, 512-14 (1964); Weaver v. Palmer Bros. Co., 270 U.S. 402, 414 (1926).

65 Ratner, The Function of the Due Process Clanse, 116 U. PA. L. Rev. 1048, 1089 (1968).

66 See, e.g., Duncan v. Louisiana, 391 U.S. 145, 149 (1968).

67 See, e.g., Rochin v. California, 342 U.S. 165, 172 (1952).

es See, e.g., Griswold v. Connecticut, 381 U.S. 479, 484 (1965).

69 Ratner, supra note 65 , at 1057.

70381 U.S. 479 (1965). Tirella cited Griswold. Tirella Brief 6.

71388 U.S. 1 (1967).

72355 Mass. at -, 249 N.E.2d at 575. 
Massachusetts considered and rejected many arguments which merited closer scrutiny.

Although the court's finding that section 213A prohibits companionship or presence itself forecloses a claim that the statute embodies an unconstitutional presumption, and although the section probably does not impose cruel and unusual punishment, the vagueness and due process arguments raised by the defendants are more compelling. The court's attempted clarification of the statutory language was inadequate, although a future decision may obviate problems of vagueness. To the extent that the statute curtails the right of free association implicitly recognized in Scales, however, it is unconstitutional.

Faced with a constitutional challenge to a provision similar to section 213A, ${ }^{73}$ the California Supreme Court in People v. Cressey ${ }^{74}$ recognized that mere presence where marijuana was being used could not be proscribed in a number of situations. ${ }^{75}$ Emphasizing that the trial court had found that the defendant had possessed the marijuana, ${ }^{76}$ the supreme court held the statute constitutionally applicable. But the opinion requires a degree of personal culpability beyond mere knowing association. The court stated:

As this court has held: "If the defendant 'did not act to aid, assist, or abet' the perpetration of the crime, he is guilty of no violation of law from the mere fact that he was present . . ." and knew of its commission. ${ }^{77}$

The Cressey court's concern with the constitutional ability of the state to penalize mere presence contrasts sharply with the view of the Massachusetts court. Clearly something more than passive presence or association is necessary to satisfy the mandates of due process-the personal culpability required in Cressey is the minimum involvement constitutionally punishable.

\section{Frank W. Molloy}

73 See Cax. Health \& Safety Code $\$ 11556$ (West 1964).

74 - Cal. 2d -, - P.2d -, 87 Cal. Rptr. 699 (1970).

75

We recognize that a literal reading of Health and Safety Code section 11556 could proscribe some kinds of conduct which cannot constitutionally be considered criminal. If one purchases a ticket and enters a motion picture theater where one has every right to remain, and midway through the film one views a person in the theater whom one knows to be smoking marijuana, must one (a) leave immediately for fear of prosecution under section 11556 , or (b) force the smoker to stop using the narcotics? An individual might find himself in situations, such as at a party, theater, or dance hall, or in a hotel lobby, bus, apartment, or taxi, or even in a private automobile, where he had no relation to the acts of others who might be disposed to use marijuana.

Id. at -, - P.2d at -, $87 \mathrm{Cal}$. Rptr. at 708 .

$76 I d$.

77 Id. (quoting People v. Woodward, 45 Cal. 293, 294 (1873)). 